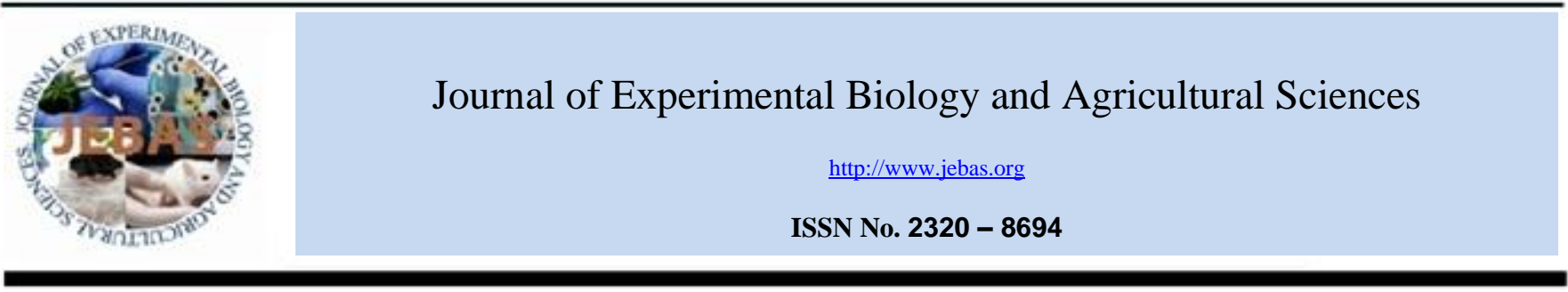

\title{
IPM APPROACH FOR THE MANAGEMENT OF WILT DISEASE CAUSED BY Fusarium oxysporum $f$. sp. lycopersici ON TOMATO (Lycopersicon esculentum)
}

\section{Hussein Ali Salim*, Iman Sahib Salman and Basheer Nsaif Jasim}

Ministry of Agriculture, Iraq

Received - October 04, 2016; Revision - November 06, 2016; Accepted - December 28, 2016

Available Online - December 30, 2016

DOI: http://dx.doi.org/10.18006/2016.4(VIS).742.747

\section{KEYWORDS}

Fulorescent Pseudomonas

Carbendazim

Spent mushroom compost

Solarized soil

Fusarium oxysporum

Wilt diseases

\section{ABSTRACT}

This study was conducted to find out the effect of combined application of fluorescent Pseudomonas, spent mushroom compost and the fungicide (Carbendazim $50 \%$ W.P) on Fusarium wilt disease infected tomato plants grown in solarized and non-solarized soil. Results of study revealed that inoculation of fluorescent Pseudomonas and spent mushroom compost have significant effect on the number and weight of tomato fruits per replicate with cost benefit ratio as compared to the control treatment having Fusarium oxysporum f.sp. lycopersici infection. No significance differences was reported among the various treatments imposed, and highest tomato fruit per plant ( 8.75 fruits/plant) was reported from the treatment containing only sterilized soil after 150 days of plantation this was followed by treatment containing $P$. fluorescens (7.35 fruits/plant), spent mushroom compost (7.00 fruits/plant), Carbendazim (7.00 fruits/plant) and spent mushroom compost with Pseudomonas fluorescens (6.90 tomato fruit/plant). Similar trends was reported in case of fruit weight and net return and treatment containing only sterilized soil show highest fruit weight $(158.60 \mathrm{~g})$, maximum net return $(113329 \mathrm{Rs} / \mathrm{ha})$ and incremental cost benefit ratio (1:4.50). While minimum net return ( $0 \mathrm{Rs} / \mathrm{ha})$ was observed in the treatment containing non sterilized soil and $F$. oxysporum infection.
* Corresponding author

E-mail: h_salim11111@yahoo.com (Hussein Ali Salim)

Peer review under responsibility of Journal of Experimental Biology and Agricultural Sciences.

Production and Hosting by Horizon Publisher India [HPI] (http://www.horizonpublisherindia.in/).

All rights reserved.
All the article published by Journal of Experimental Biology and Agricultural Sciences is licensed under a Creative Commons Attribution-NonCommercial 4.0 International License Based on a work at www.jebas.org.

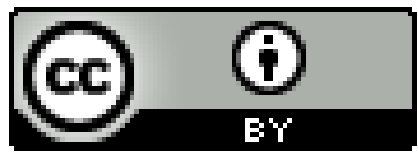




\section{Introduction}

Tomato (Lycopersicon esculentum Mill) is an important vegetable crop which widely grown by both small and large scale farmers; even it is common in kitchen and home gardens too. It's good source of Vitamins A, B and C and also ripens fruits is have antibiotic properties which is helpful in healing wounds (Baloch, 1994). Wilts disease of tomato is caused by Fusarium oxysporum f.sp. lycopersici. It is one of the highly destructive tomato disease which caused infection even in plant grown in greenhouse (Larkin \& Fravel, 1998; Borrero et al., 2004). The pathogen enters through the plant roots and proliferates in the vascular tissues leading to breakdown of the water supply of the infected plants (Agrios, 2005). Typical symptoms of the disease are yellowing and wilting of leaves and it progressing upward from the base of the stem. Initially, only one side of a plant is affected but after some time these symptoms spread to the rest of the plant and finally kill the plant. Due to prolonged survival in soil as a saprophyte and as resistant structures, $F$. oxysporum is difficult to control (Khan \& Khan, 2002; Borrero et al., 2004). Tomato yield loss due to F. oxysporum infection varies between 10 to $90 \%$ and it depends on the stage of the plant growth and the environmental conditions (Kumar \& Sood, 2002; Singh, 2005).

Wilt disease of tomato can be easily control by the application of chemical fertilizers, but excess use of chemical fertilizers not only affect the quality of tomato fruit but also cause environmental pollution. Further, chemical fertilizers also caused severe damage to not target organisms. Now in these days, most of the researchers worked on the searching of alternative approach for the management of this disease. Various bio-control organisms help in reducing this pathogen infection. Among these Pseudomonads fluorescens is a nonpathogenic rhizobacteria which suppress the soil-borne pathogens through rhizosphere colonization, antibiosis and iron chelation by siderophore production (Elad \& Chet, 1987; Lemanceau et al., 1992; Pierson \& Thomashow, 1992). Further, these bacteria have ability to promote plant growth, either by directly stimulating the plant or by suppressing pathogens (Ross et al., 2000; Haas \& Defago, 2005; Carlier et al., 2008; Rovera et al., 2008; Rosas et al., 2009; Srinivasan et al., 2009). Various researchers have been tested the antagonistic properties of F.oxysporum (Madi et al., 1997; Tsahouridou \& Thanassoulopoulos, 2002; Errakhi et al., 2007). Further researchers also established the fact that $F$. pseudomonads can be used as a biological control agent against $F$. oxysporum (Elad, 1995; Singh et al., 2003).

Soil solarization is also a common practice for managing soil born diseases; it's affect soil health, plant growth, crop yield, and quality of crop plants (Katan, 1987).

Like other management practices, soil solarization also used to control tomato wilt disease, (Ioannou et al., 2000; Tamietti \& Valentino, 2006). Barakat \& AL-Masri (2012) carried out soil solarization for the management of $F$. oxysporum f. sp. lycopersici, for seven weeks from July to August 2008 and
2009 and reported significant reduction in the population of the pathogen. Further, Raj \& Kapoor, (1997) reported that mushroom compost also enhancing microbial activity in the amended soil and higher dosage $(2 \%, \mathrm{w} / \mathrm{w})$ of composts are most effective in managing the pathogen $F$. oxysporum $\mathrm{f}$. sp. Iycopersici, therefore it can be use for better plant health and disease control. It was well reported that mushroom compost (spent mushroom substrate, SMS, mushroom soil) exhibits suppressive characteristics against various fungi, as well as against plant diseases caused by fungi. In addition, mushroom compost has physical and chemical characteristics that make it ideal for blending with landscape mulch to enhance growth of horticultural plants (Davis et al., 2005). Incorporation of composted Spent Mushroom Substrate (SMS) not only improves the nutrient status but also neutralizes the acidity of soils (Pannier, 1993; Ahlawat et al., 2005) and facilitates cultivation even in problematic soils (Ahlawat et al., 2011). In addition, SMS also possesses good bio-control activity against certain foliar and soil borne diseases (Yohalem et al., 1996; Ahlawat et al., 2007).

Ajay \& Shashi (2012) reported that effective control by 10 minute dipping of tomato seedlings roots in $0.3 \%$ solution of Carbendazim 50 WP before transplanting inhibited wilt disease caused by $F$. oxysporum f. sp. lycopersici. Amini (2009) evaluated carbendazim against $F$. oxysporum f. sp. lycopersici in vivo, the result of glasshouse tests revealed efficacy of fungicide in reducing disease infestation. The aim of this study was to evaluate the number of tomato fruits and cost benefit ratio of yield by using IPM approach with fluorescent Pseudomonas, soil solarization, spent mushroom compost and fungicide (Carbendazim).

\section{Materials and Methods}

This pot study was conducted during 2014 under net house condition at Sam Higginbottom Institute of Agriculture, Technology and Sciences, Allahabad, India. Experimental pots were laid out in Complete Randomized Block Design (CRBD) with six treatments and five replicates. Pot used in this study was of $10 \mathrm{~cm}$ in diameter and with capacity of $10 \mathrm{~kg}$ soil. Pots soil was artificially contaminant by adding pure culture of $F$. oxysporum f. sp. lycopersici @ $2 \mathrm{~g} / \mathrm{kg}$ soil, this pure culture was multiplied on sorghum grains.

\subsection{Process of soil solarization}

Soil solarization was conducted for 2 months from $15^{\text {th }}$ April to $15^{\text {th }}$ June 2013 at research field of SHIATS, Allahabad. Soil was solarized with the help of $40 \mu \mathrm{m}$ thick polythene sheet, soil was properly irrigated before laying the polythene sheet.

2.2 Source of Tomato seeds, fluorescent Pseudomonas, Spent mushroom compost and pathogen

Seeds of local tomato variety (CO-3) were collected from Indian Institute of Vegetable Research), Varanasi, Uttar 
Pradesh, India. Healthy seeds were selected manually and used for study. Fluorescent Pseudomonas was acquired from Yash Trichoguard, DBT Referral Lab, SHIATS, Allahabad, Uttar Pradesh, India while the culture of spent mushroom compost and $F$. oxysporum was acquired from Department of Plant Pathology, Sam Higginbottom Institute of Agriculture, Technology \& Sciences, Naini, Allahabad. Pure culture of $F$. oxysporum was maintained on czapek's dox agar and mass culture of $F$. oxysporum was maintained on sorghum grains.

2.3 Application of fluorescent Pseudomonas, carbendazim and Spent mushroom compost

The solarized and unsolarized soil was mixed with FYM @ $100 \mathrm{~g} / \mathrm{pot}$ and filled in the experimental pots. Tomato seeds were treated with bioagent $P$. fluorescens and chemical fertilizer Carbendazim @ 4g $/ 1 \mathrm{~kg}$ seeds and shown in the pot @ 10 seeds per ponds. Simultaneously pot soil was inoculated with P. fluorescens and Carbendazim @ 2 g/pot. Ten pots were supplemented with spent mushroom compost @ $20 \mathrm{~g} /$ $\mathrm{kg}$.

\section{Results and Discussion}

3.1 Effect of various treatments on fruit production

All studied combinations have statistically significant difference than the control (Non sterilized soil along with $F$. oxysporum inoculation). Among various tested treatments, treatment containing only sterilized soil without $F$. oxysporum shows superiority over the rest of the treatments and gave average 8.75tomato fruit/plant after 150 days of plantation. This fruit number was followed by treatment containing solarized soil containing P. fluorescens (7.35 tomato fruit/plant), solarized soil along with spent mushroom compost (7.00 tomato fruit/plant), solarized soil and Carbendazim (7.00 tomato fruit/plant) and spent mushroom compost with $P$. fluorescens (6.90 tomato fruit/plant). These three treatments are not statistically different among themselves. Similar, type of findings was reported by Haruna et al. (2011) when they tried carbendazim for wilt disease management in tomato plant.

These researchers reported $12 \%$ improvement in fruit production rate on the application of carbendazim and compost. Average weight of five tomato fruits per replicate (g) was also significantly different and varies with the treatments. Like fruit numbers, treatment containing only solarized soil show superiority $(158.60 \mathrm{~g})$ over all the other studied treatments. This fruit weight was followed by the combination of solarized soil and Carbendazim $(132.50 \mathrm{~g})$, solarized soil along with spent mushroom compost $(131.60 \mathrm{~g})$, solarized soil along with $P$. fluorescens $(116.20 \mathrm{~g})$ and spent mushroom compost with $P$. fluorescens $(97.20 \mathrm{~g})$. These treatments are significantly different that the control (Non Solarized soil $+F$. oxysporum) but are not significantly different when compare with each other except compost with $P$. fluorescens. These results are in agreement in the findings of Seleim et al. (2011) those have reported highest increases in tomato yield by the application of $P$. fluorescens.

\subsection{Cost benefit ratio}

Data with respect to agronomical practices were same for all treatments (Table 2) while the economic values of all treatments were significantly different between treatments (Table 3). Like fruit characteristics, maximum net return (113329 Rs/ha) was recorded from the treatment containing solarized soil, this cost benefit ration was followed by treatment containing solarized soil with $P$. fluorenscens (72871 Rs/ha), Carbendazim (67819 Rs/ha), Spent mashroom compost, (58329 Rs/ha) and Spent mashroom compost with $P$. fluorenscens (40617 Rs/ha). The minimum net return (0 Rs/ha) was observed from the treatment containing Non solarized soil along with $F$. oxysporum.

Table 1 Effect of spent mushroom compost, P. fluorescens and carbendazim using solarized and unsolarized soil on the number of fruits and fruits weight.

\begin{tabular}{|c|c|c|c|c|}
\hline \multirow[t]{3}{*}{ Treatments } & \multicolumn{3}{|c|}{ Average number of fruits / plant } & $\begin{array}{l}\text { Average weight of five } \\
\text { fruits / replicate (g) }\end{array}$ \\
\hline & \multicolumn{4}{|c|}{ Days } \\
\hline & 90 & 120 & 150 & 125 \\
\hline Non SS along with $F o$ & 0.00 & 1.00 & 3.00 & 25.00 \\
\hline SS along with Smc and $F_{O}$ & 1.70 & 5.85 & 7.00 & 131.60 \\
\hline SS along with $P f$ and $F o$ & 0.80 & 6.15 & 7.35 & 116.20 \\
\hline SS in combination with $\mathrm{Smc}+P f+F o$ & 0.25 & 5.80 & 6.90 & 97.20 \\
\hline $\mathrm{SS}$ along with $\mathrm{C}+F o$ & 3.25 & 5.75 & 7.00 & 132.50 \\
\hline SS along with tomato plant & 1.20 & 4.75 & 8.75 & 158.60 \\
\hline C. D. $(P=0.05)$ & 1.765 & 1.974 & 1.809 & 29.038 \\
\hline
\end{tabular}

Here SS - Solarized soil; Fo-F. oxysporum; Smc-Spent mashroom compost; C-Carbendazim and Pf- P. fluorenscens 
Table 2 Estimated Cost of production based on the amount spend on agronomical practices for cultivation/ha (Pot data is converted in to field data).

\begin{tabular}{|c|c|c|c|c|}
\hline Sr. No. & Particular & Requirement & Rate/unit Rs. & Cost (Rs) \\
\hline (A) & Land preparation & & & \\
\hline I. & Ploughing & 3 hours & 500 Rs/hours & 1500 \\
\hline II. & Harrow & 3 hours & 500 Rs/hours & 1500 \\
\hline III. & Layout of field & 10 labours & $150 \mathrm{Rs} / \mathrm{labour}$ & 1500 \\
\hline (B) & $\begin{array}{l}\text { Manures and } \\
\text { fertilizer }\end{array}$ & & & \\
\hline I. & FYM & 20 tons & $100 \mathrm{Rs} / \mathrm{qu}$. & 20000 \\
\hline II. & Urea & $193 \mathrm{Kg}$ & $7 \mathrm{Rs} / \mathrm{Kg}$ & 1351 \\
\hline III. & DAP & $174 \mathrm{Kg}$ & $15 \mathrm{Rs} / \mathrm{Kg}$ & 2610 \\
\hline IV. & Labour & 6 labours & 150 & 900 \\
\hline (C) & Seed sowing & & & \\
\hline I. & Seed material & $0.5 \mathrm{~kg}$ & $1500 \mathrm{Rs} / \mathrm{Kg}$ & 750 \\
\hline II. & $\begin{array}{l}\text { transplanting and } \\
\text { leveling }\end{array}$ & 12 labours & 150 & 1800 \\
\hline (D) & Weed Management & 15 labour X3 time & $150 \mathrm{Rs} /$ labour & 6750 \\
\hline (E) & Harvesting & 30 labours & $150 \mathrm{Rs} / \mathrm{labour}$ & 4500 \\
\hline (F) & $\begin{array}{l}\text { Total cost of } \\
\text { cultivation }\end{array}$ & & & 25161 \\
\hline
\end{tabular}

Table 3 Estimated cost of various treatments formulation.

\begin{tabular}{|lccc|} 
Treatments & Cost of Smc + Pf + carbendazim $(\mathrm{Rs})$ & Labor cost $(\mathrm{Rs})$ & Total Cost $(\mathrm{Rs})$ \\
\hline Non SS along with $F o$ & 0 & 0 & 0 \\
\hline $\mathrm{SS}$ along with $\mathrm{Smc}$ and $F o$ & 20000 & 900 & 20900 \\
\hline $\mathrm{SS}$ along with $P f$ and $F o$ & 200 & 900 & 1100 \\
\hline $\mathrm{SS}$ in combination with $\mathrm{Smc}+P f+F o$ & 20200 & 900 & 21100 \\
\hline $\mathrm{SS}$ along with $\mathrm{C}+F o$ & 280 & 0 & 1180 \\
\hline $\mathrm{SS}$ along with tomato plant & 0 & 0 \\
\hline
\end{tabular}

Here SS - Solarized soil; Fo-F. oxysporum; Smc - Spent mashroom compost; C-Carbendazim and Pf- P. fluorenscens

Similarly, maximum cost benefit ratio and incremental cost benefit ratio were obtained with treatment containing solarized soil (1:4.50), this was followed by the treatment containing solarized soil along along with $P$. fluorenscens (1:2.77), Carbendazim (1:2.57), Spent mashroom compost (1:1.26), and Spent mashroom compost with $P$. fluorenscens (1:0.87). The minimum cost $(0)$ benefit ratio and incremental cost benefit ratio was reported from Non solarized soil with $F$. oxysporum (Table 4).

\section{Conflict of interest}

Authors would hereby like to declare that there is no conflict of interests that could possibly arise.

Journal of Experimental Biology and Agricultural Sciences

http://www.jebas.org

\section{References}

Agrios GN (2005) Plant Pathology. 5" Edition. Academic Press, San Diego, USA

Ahlawat OP, Manikandan K, Sagar MP, Dev Raj, Gupta P, Vijay B (2011) Effect of composted button mushroom spent substrate on yield, quality and disease incidence of Pea (Pisum sativum) Mushroom Research 20 : 87-94.

Ahlawat OP, Rani C Indu, Sagar MP (2005) Spent mushroom substrate properties and recycling for beneficial purposes. In: Rai RD, Upadhyay RC, Sharma SR (Eds.) Frontiers in Mushroom Biotechnology, National Research Centre for Mushroom, Solan, India, Pp 314-334. 
Table 4 Impact of various treatments on the Cost benefit ratio of tomato.

\begin{tabular}{|c|c|c|c|c|c|c|c|c|c|c|c|c|}
\hline Treatments & $\mathbf{M}$ & $\mathbf{N}$ & $\mathbf{A}$ & D & $\mathbf{E}$ & $\mathbf{F}$ & G & B & H & $\mathbf{O}$ & $\mathbf{C}$ & \\
\hline & 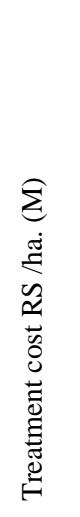 & 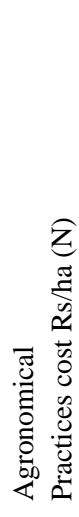 & 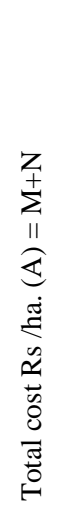 & 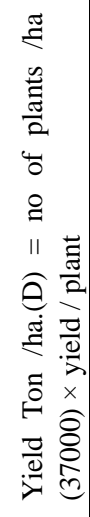 & 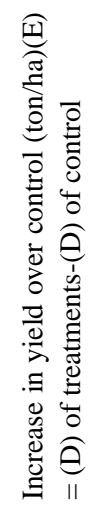 & 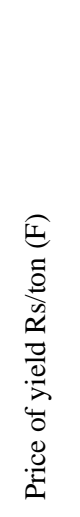 & 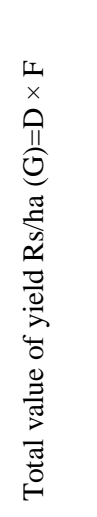 & 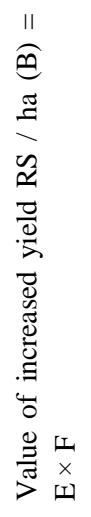 & 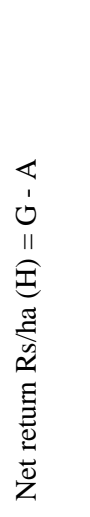 & 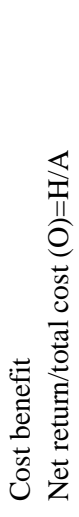 & 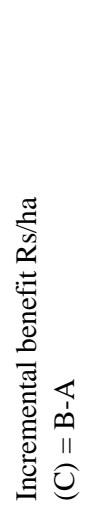 & 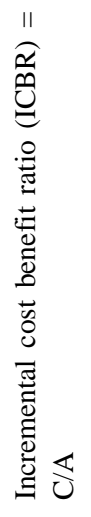 \\
\hline $\begin{array}{l}\text { Non SS along } \\
\text { with } F o\end{array}$ & 0 & 25161 & 25161 & 0 & 0 & 22000 & 0 & 0 & 0 & 0 & 0 & 0 \\
\hline $\begin{array}{l}\text { SS along with } S m c \\
\text { and } F o\end{array}$ & 20900 & 25161 & 46061 & 4.745 & 4.745 & 22000 & 104390 & 104390 & 58329 & $1: 1.26$ & 58329 & $1: 1.26$ \\
\hline $\begin{array}{l}\text { SS along with } P f \\
\text { and } F o\end{array}$ & 1100 & 25161 & 26261 & 4.506 & 4.506 & 22000 & 99132 & 99132 & 72871 & $1: 2.77$ & 72871 & $1: 2.77$ \\
\hline $\begin{array}{l}\text { SS in combination } \\
\text { with } \mathrm{Smc}+\mathrm{Pf}+ \\
\text { Fo }\end{array}$ & 21100 & 25161 & 46261 & 3.949 & 3.949 & 22000 & 86878 & 86878 & 40617 & $1: 0.87$ & 40617 & $1: 0.87$ \\
\hline $\begin{array}{l}\text { SS along with } \mathrm{C} \\
+F o\end{array}$ & 1180 & 25161 & 26341 & 4.280 & 4.280 & 22000 & 94160 & 94160 & 67819 & $1: 2.57$ & 67819 & $1: 2.57$ \\
\hline $\begin{array}{l}\text { SS along with } \\
\text { tomato plant }\end{array}$ & 0 & 25161 & 25161 & 6.295 & 6.295 & 22000 & 138490 & 138490 & 113329 & $1: 4.50$ & 113329 & $1: 4.50$ \\
\hline
\end{tabular}

Here SS - Solarized soil; Fo-F. oxysporum; Smc - Spent mashroom compost; C-Carbendazim and Pf- P. fluorenscens.

Ahlawat OP, Sagar MP, Raj Dev, Rani C Indu, Gupta Pardeep, Vijay B (2007) Effect of spent mushroom substrate on yield and quality of capsicum. Indian Journal of Horticulture 64 : 430-434.

Ajay KS, Shashi K (2012) Chemical Control of Wilt in Tomato (Lycopersicon esculentum L.). International Journal of Horticulture 2: 5-6. DOI: 10.5376/ijh.2012.02.0002.

Amini J (2009) Physiological race of Fusarium oxysporum f.sp. lycopersici in Kurdistan province of Iran and reaction of some tomato cultivars to race 1 of pathogen. Plant Pathology Journal 8: 68-73. DOI: 10.3923/ppj.2009.68.73.

Baloch FA (1994) Vegetable crops. In: Horticulture. National Book Foundation, Islamabad. Pp 508.

Barakat RM, AL-Masri MI (2012) Enhanced Soil Solarization against Fusarium oxysporum f.sp. lycopersici in the Uplands. International Journal of Agronomy, Volume 2012, Pp 7. http://dx.doi.org/10.1155/2012/368654.

Borrero C, Trillas MI, Ordovás J, Tello JC, Avilés M (2004) Predictive factors for the suppression of fusarium wilt of tomato in plant growth media. Phytopathology 94 :1094 1101. doi: 10.1094/PHYTO.2004.94.10.1094.

Carlier E, Rovera M, Rossi Jaume A, Rosas SB (2008) Improvement of growth, under field conditions, of wheat inoculated with Pseudomonas chlororaphis subsp. aurantiaca SR1. World Journal of Microbiology and Biotechnology 24 : 2653-2658. doi:10.1007/s11274-008-9791-6.

Davis DD, Kuhns LJ, Harpster TL (2005) Use of Mushroom Compost to Suppress Artillery Fungi. Journal of Environmental Horticulture 23 : 212-215.

Elad Y (1995) Mycoparasitism. In: Kohmoto K, Singh US, Singh RP (Eds.) Pathogens and Host Specificity in Plant diseases, II, Eucaryotes, Pp. 285-307. Pergamon Press, Oxford, UK.

Elad Y, Chet I (1987) Possible role of competition for nutrition in biocontrol of Pythium damping-off by bacteria. Phytopathology 77: 190-195.

Errakhi R, Bouteau F, Lebrihi A, Barakate M (2007) Evidences of biological control capacities of Streptomyces spp Against Sclerotium rolfsii responsible for damping-off disease 
in sugar beet (Beta vulgaris L.).World Journal of Microbiology and Biotechnology 23: 1503-1509. doi:10.1007/s11274-0079394-7.

Haas D, Defago G (2005) Biological control of soil-borne pathogens by fluorescent pseudomonads. Nature Reviews Microbiology 3: 307-319. doi:10.1038/nrmicro1129.

Haruna SA, Adebitan SA, Gurama AU (2011) In vitro Evaluation of the Efficacy of Compost Extracts on Fusarium oxysporum f. sp. lycopersici the Causal Agent of Tomato Wilt. Savannah Journal Agriculture 6: 25 - 31.

Ioannou N, Poullis CA, Heale JB (2000) Fusarium wilt of watermelon in Cyprus and its management with soil solarization combined with fumigation or ammonium fertilizers. EPPO Bulletin 30: 223-230. DOI: 10.1111/j.13652338.2000.tb00884.x.

Katan J (1987) Soil solarization. In: Chet I (Ed.) Innovative Approaches to Plant Disease Control. Wiley, New York, pp. 77-105.

Khan MR, Khan SM (2002) Effects of root-dip treatment with certain phosphate solubilizing microorganisms on the fusarial wilt of tomato. Bio Resource Technology 85: 213-215.

Kumar P, Sood AK (2002) Control of bacterial wilt of tomato with VAM and bacterial antagonists. Indian Phytopathology 55: 513 .

Larkin RP, Fravel DR (1998) Efficacy of various fungal and bacterial biocontrol organisms for the control of Fusarium wilt of tomatoes. Plant Disease 82: 1022 - 1028.

Lemanceau P, Bakker PA, De Kogel WJ, Alabouvette C, Schippers B (1992) Effect of pseudobactin 358 production by Pseudomonas putida WCS358 on suppression of fusarium wilt of carnations by nonpathogenic Fusarium oxysporum Fo47. Applied and Environmental Microbiology 58 :2978-2980.

Madi L, Katan T, Katan J, Henis Y (1997) Biological control of Sclerotium rolfsii and Verticillium dahliae by Talaromyces flavus is mediated by different mechanisms. Phytopathology 87: 1054-1060. doi: 10.1094/PHYTO.1997.87.10.1054.

Pannier W (1993) Spent mushroom compost, a natural resource that provides solutions to environmental problems. Mushroom News 41: 10-11.

Pierson LS 3rd, Thomashow LS (1992) Cloning and heterologous expression of the phenazine biosynthetic locus from Pseudomonas aureofaciens 30-84. Molecular PlantMicrobe Interactions Journal 5:330-339.

Raj H, Kapoor IJ (1997) Possible management of Fusarium wilt of tomato by soil amendments with composts. Indian Phytopathology 50: 387-395 .
Rosas SB, Avanzini G, Carlier E, Pasluosta C, Pastor N, Rovera M (2009) Root colonization and growth promotion of wheat and maize by Pseudomonas aurantiaca SR1. Soil Biology and Biochemistry 41: 1802-1806. DOI: http://dx.doi.org/10.1016/j.soilbio.2008.10.009.

Ross IL, Alami Y, Harvey PR, Achouak W, Ryder MH (2000) Genetic diversity and biological control activity of novel species of closely related pseudomonads isolated from wheat field soils in South Australia. Applied and Environmental Microbiology 66: 1609-1616. doi: 10.1128/AEM.66.4.16091616.2000

Rovera M, Andres J, Carlier E, Pasluosta C, Rosas S (2008) Pseudomonas aurantiaca: plant growth promoting traits, secondary metabolites and inoculation response. In: Ahmad I, Pichtel IJ, Hayat S (Eds.) Plant-Bacteria Interactions. Strategies and Techniques to Promote Plant Growth, WileyVCH, Weinheim, Germany, Pp 155-164.

Seleim MAA, Saead FA, Abd-El-Moneem KMH , AboELyousr KAM (2011) Biological Control of Bacterial Wilt of Tomato by Plant Growth Promoting Rhizobacteria. Plant Pathology Journal 10 : 146-153. DOI: 10.3923/ppj.2011.146.153.

Singh A, Mehta S, Singh HB, Nautiyal CS (2003) Biocontrol of collar rot disease of betelvine (Piper betle L.) caused by Sclerotium rolfsii by using rhizosphere-competent Pseudomonas fluorescens NBRI-N6 and P. fluorescens NBRIN. Current Microbiology 47: 153-158.

Singh RS (2005) Plant diseases, Eighth Edition, Oxford \& IBH Publishing Co.Pvt Ltd., New Delhi, Pp 78.

Srinivasan K, Gilardi G, Garibaldi A, Gullino ML (2009) Bacterial antagonists from used rockwool soiless substrates suppress fusarium wilt of tomato. Journal of Plant Pathology 91: $147-154$

Tamietti G, Valentino D (2006) Soil solarization as an ecological method for the control of Fusarium wilt of melon in Italy. Crop Protection 25 : 389-397. DOI: http://dx.doi.org/10.1016/j.cropro.2005.07.002.

Tsahouridou PC, Thanassoulopoulos CC (2002) Proliferation of Trichoderma koningii in the tomato rhizosphere and the suppression of damping-off by Sclerotium rolfsii. Soil Biology and Biochemistry 34 : 767-776. DOI: http://dx.doi.org/10.1016/S0038-0717(02)00006-8.

Yohalem, DS, Nordheim EV, Andrew JH ( 1996) Effect of water extracts of spent mushroom compost on apple scab in the field. Phytopathology 86 : 914- 922. 